\title{
A FEW ETHNOLOGICAL SPECIMENS COLLECTED BY LEWIS AND CLARK ${ }^{1}$
}

\section{BY CHARLES C. WILLOUGHBY}

The loss to American ethnology by the breaking up and partial destruction of the earlier collections of examples of modern Indian handicraft can be appreciated only by those familiar with the comparatively few remaining specimens of the ligher class of these objects collected previous to the middle of the nineteenth century. The relatively small collection brought together by Catlin, for example, probably contained more choice specimens of the earlier handiwork of the modern tribes of the Siouan culture area than all the museums of America can ever hope to bring together from other sources. A few of the objects collected by Catlin escaped destruction and are preserved in the National Museum, the Free Museum of Science and Art of Philadelphia, and the Peabody Museum of Harvard University. These examples, however, represent but a very small part of the original collection.

The ethnological material brought together by Gov. William Clark in his museum at St Louis seems to have suffered a fate similar to that of the greater portion of the Catlin collection. Many of Governor Clark's specimens were probably collected by the Lewis and Clark expedition. Catlin, being a friend of Clark's, had access to his museum and profited by it. $\mathrm{He}$ also obtained from Clark a number of objects from the Columbia river region which are generally supposed to have been collected by Catlin. Some of these are in the National Museum. There are in the Peabody Museum at Cambridge two Chinook ciadles and a wedge for splitting wood which were in the Catlin collection and doubtless originally belonged to Clark's museum.

The first winter quarters of the Lewis and Clark expedition, Fort Mandan, was situated on the left bank of the Missouri, seven

${ }^{1}$ Presented at the meeting of the American Anthropological Association, Berkeley, California, August 3 I. 
or eight miles below the mouth of Knife river, in central North Dakota. It was in the heart of the Indian country, and the members of the expedition were in communication not only with the Indians of that vicinity but with the Assiniboin, Cree, and other remote tribes. This afforded an unusual opportunity for collecting objects illustrating the ethnography of the region. It will always be a source of regret that such an opportunity was allowed to pass with so little accomplished.

On April 3,1805, the packing of the articles obtained during the winter was completed and a list prepared of the specimens contained in the three cages, four boxes, and large trunk. These were sent to St Louis upon the barge which started on its return trip on April 7. They "reached Mr Jefferson and some of them were long on view at Monticello. Others passed to Peale's Museum in Philadelphia." 1 A list of these objects can be found in the first volume of the recently published "Original Journals of the Lewis and Clark Expedition." In the following condensed list only the ethnological material is enumerated in detail.

Box I : A Mandan bow and quiver of arrows with some Arikara tobacco seed, besides several natural history specimens.

Box 2: Four buffalo robes and an ear of Mandan corn.

Box 4: Natural history specimens and "an earthen pot such as the Mandans manufacture and use for culinary purposes."

In the large trunk were packed several natural history specimens, some Arikara tobacco, a Mandan robe, a " buffalo robe painted by a Mandan man representing a battle fought eight years since by the Sioux and Recaras [Arikara] against the Mandans, Menitarras and Ah-wah-har-ways [Amahawi], Mandans \&c on horse back." Also a Minnetaree buffalo " robe containing some articles of Indian dress," which unfortunately are not listed in detail. It is very probable, however, that the objects shown in plates xxxvil and xxxviII, $a, b$, were a part of the contents of this package.

The Charles Wilson Peale Museum, at Philadelphia, where many of the specimens collected by this expedition were sent either by $\mathrm{Mr}$ Jefferson or by Lewis and Clark personally, was established in 1785 and had a successful existence of nearly fifty years. It was

1 Elliott Coues, History of the Lewis and Clark Expedition, vol. I, p. 250, note. 


$$
\bar{E}
$$



finally discontinued and a part of its collections, probably a majority, passed to the well-known Boston Museum which in its earlier days was as noted for its cases of wax figures, its ethnological and natural history collections, and historical objects as for its theater. In the winter of $1898-99$, a fire broke out in the Boston Museum, but did little damage to the collections in the exhibition galleries. In the following spring the interior of the building was repaired and partially remodeled, and the museum which gave to the famous playhouse its name was discontinued, the collections being distributed as gifts among the museums of Boston and vicinity. The Peabody Museum of Harvard University received the valuable ethnological collection, which included the following objects as well as several other specimens probably also collected by Lewis and Clark, including the Mandan bow noted in the above list. The label belonging with the bow has unfortunately been lost and there is no satisfactory proof of its identity.

\section{Raven Skin Badges of Office}

Plate Xxxvin, $a, b, c$, shows three badges of office such as were worn by certain individuals belonging to various tribes of the Siouan and other linguistic families. The group shown at $a$ was attached to the back of the girdle in such a way as to stand out horizontally. Those shown at $b, c$, hung, one from each arm, at the elbow. Similar ornaments are seen in position in portraits painted by King and Catlin. These badges were worn by trustworthy men appointed by the chief. An idea of their duties may be derived from the following account by Lewis and Clark ${ }^{1}$ of one seen among the Teton Okandanda :

"While on shore to-day we witnessed a quarrel between two squaws, which appeared to be growing every moment more boisterous, when a man came forward, at whose approach every one seemed terrified and ran. He took the squaws and without any ceremony whipped them severely. On inquiring into the nature of such summary justice we learned that this man was an officer well known to this and many other tribes. His duty is to keep the peace, and the whole interior police of the village is confided to two or three of these officers who are named by the chief

\footnotetext{
'Lewis and Clark, op. cit., pp. 140, I4I.
} 
and remain in power some days, at least till the chief appoints a successor. They seem to be a kind of constable or sentinel, since they are always on the watch to keep tranquility during the day and guard the camp at night. The short duration of the office is compensated by its authority. His power is supreme, and in the suppression of any riot or disturbance no resistance to him is suffered; his person is sacred, and if in the execution of his duty he strikes even a chief of the second class, he cannot be punished for this salutary insolence. In general he accompanies the person of the chief and when ordered to any duty, however dangerous, it is a point of honor rather to die than to refuse obedience. Thus when they attempted to stop us yesterday, the chief ordered one of these men to take possession of the boat; he immediately put his arm around the mast, and, as we understood, no force except the command of the chief would have induced him to release his hold. Like the other men his body is blackened but his distinguishing mark is a collection of two or three ravens' skins fixed to the girdle behind the back in such a way that the tails stick out horizontally from the body. On his head too is a raven-skin split into two parts, and tied so as to let the beak project from the forehead."

The badge worn at the back ( $\mathrm{pl}$. xxxvil, a) consists of an oblong piece of rawhide to which are attached four raven skins with the legs removed. These are in a fairly good state of preservation, although but one retains all of its symbolic appendages. The front part of each skin is stuffed with a roll of buckskin which projects and is turned upward and backward. The beak and skin of the head and neck are fastened to the end of this roll so that the beak rests upon the back of the skin, as shown more clearly in the arm ornament, $b$. The upper mandible is perforated about half an inch from its tip and to it, at this point, are attached four of the inner webs stripped from the tail-feathers of the hawk or the owl. These webs have been dyed red.

At a point between the base of the bill and the eye is attached, upon each side, a loop of rawhide about three inches in length. The strip forming the loop is about one-fourth of an inch in width and is wound with porcupine quills or thin strips from feather shafts, dyed. The outer third of the loop is red, the inner two thirds yellow. These colors are separated by a single brown quill. At the base of each loop, and fastened to it by sinew wrappings, is a tuft of horsehair, about twelve inches long, dyed red. 
The wings are closed and brought together beneath the body and tied with sinew. A carefully finished strip of hard wood, about eleven inches long and a little more than a fourth of an inch wide, is fastened to the inner side of the outer quills of each wing. These are wrapped with porcupine quills in their natural color or dyed red, and what appear to be split roots colored black. These wrappings are arranged so as to form bands and figures which vary in the different birds. Each end of the stick is ornamented with a tuft of horse-hair, dyed red, wrapped with a strip of ermine skin where it is attached to the stick. Both tufts fall in the same direction away from the head.

A third strip of wood, a little wider than the others and ornamented in the same way, is joined to the base of the tail beneath the coverts and extends along the upper side, where it is fastened to the shafts of the upper feathers. The design formed by the arrangement of the quill wrappings upon these tail-pieces was evidently the same in each of the four birds. Beginning at the base of the tail for a space of about an inch, the wrapping is of white quills followed by black squares upon a white ground, then two inches of white with a black cross in the center, then an inch and a half of alternating brown and white transverse stripes. Below this are three inches of orange divided into three sections by bands of white, each two quills in width.

The central portion of the web of the feathers upon one side of each tail has been stripped from each side of the shafts for about three inches with the exception of the central feathers and the outer feather which have the web removed from the inner side only. Two of the birds have the webs removed from the left side of the tail and two from the right side.

The raven ornaments worn at the elbow (pl. xxxvir, $b, c$ ) lack the four pendant feathers of the beak, and the webs have not been stripped from one side of the tail. The quill designs also differ slightly, otherwise they are the same as the four skins forming the back piece. Specimen $b$ is in nearly perfect condition, but $c$ is somewhat dilapidated. It is probable that the three pieces belonged to the same outfit.

One of the arm-pieces was accompanied with an old printed label 
of the Peale Museum which reads: "Ornament. Worn upon the elbow by the Sioux Indians. Collected by Captains Lewis and Clarke."

\section{Mandan Buffalo Robe}

The label belonging with the specimen shown in plate xxxviII, $c$, has been lost, but there can be no question as to the identity of the robe. We learn from the list, already quoted, that the battle represented thereon was fought about the year 1797 by the Sioux and Arikara against the Mandan, Minnetaree, and "Ah-wah-har-ways," and that the "Mandans \&c" were on horseback. There are sixtyfour Indians shown in the painting, twenty of whom are mounted. With one exception the figures are outlined in brownish-black. This exception is the mounted warrior just above the middle of the central line of quills and to the left of the stooping figure shooting an arrow. This mounted Indian is red with black head and hair. He carries a green shield with concentric circles of red, having a yellow center. Some of the other shields are painted with these colors, differently grouped. The horses are outlined in brownish black. Some of their bodies are painted brown, others yellow or red. A few "calico" horses are represented.

The contestants are armed with spears, bows and arrows, guns, and tomahawks, a few individuals having both guns and bows and arrows. A number are shown in the act of shooting arrows, throwing spears, or striking with tomahawks. The latter weapon is represented sticking in the head of two or three individuals.

The central dividing line is wrought with porcupine quills in white, black, green, red, and yellow. It is probably symbolic of a path or trail connected in some way with the battle shown in the picture.

\section{Otter-skin Bag}

The quill-ornamented otter-skin bag shown in plate $\operatorname{xxxvII,} d$, is an unusually fine example of a "medicine-bag" used in the ceremonies of the widely distributed Shell Society and as a receptacle for the shell and other sacred objects. Catlin figures similar bags which he calls tobacco pouches. The old printed label of the Peale Museum accompanying this reads as follows: "Sioux Tobacco Pouch. Sent to Capts. Lewis and Clark by the Sock [Sauk] Nation. Presented 
by Capts. Lewis and Clarke." The skin is uncut with the exception of a slit in the throat through which the body of the animal was removed, and the underside of the tail which was split its entire length and opened flat. The feet, underside of the tail, and the anal opening are covered with pieces of buckskin dressed without the hair and ornamented with elaborate designs in porcupine quills, the colors being black, white, and orange. The tail-piece is bordered upon the sides and the feet coverings upon their lower edges with pendants of tin and deer hair. A looped ornament of buckskin wrapped with quills is fastened to each ear. These probably have a significance similar to that of the looped ornaments at each side of the ravens' heads illustrated in the same plate.

\section{Cree Women's Dresses}

The two garments shown in plate xxxvirl $a, b$, are of unusual interest, as they illustrate a very rare type of dress. They were undoubtedly obtained from the party of Cree (Knisteneaux) that came down from the vicinity of the Saskatchewan river in November, I 804, to Fort Mandan. Clark writes: "Our Interpeter informs that 70 Lodges one of 3 bands of Assinniboins \& some Crestinoes [Knisteneaux] are at the Mandan Village. The Crestinoes are abt 300 (240) men Speak the Chipaway Language the [y] live near Fort De prari (on Assiniboin \& Assaskashawan) they are bands of the Chippeways." "

The native dress of a Knisteneaux woman is thus described by Mackenzie :"

"The female dress is formed of the same material [moose skin] as those of the other sex but of a different make and arrangement. Their shoes are commonly plain and their leggings gartered beneath the knee. The coat or body covering falls down to the middle of the leg and is fastened over the shoulder with cords, a flap or cape turning down about eight inches before and behind and agreeably ornamented with quill work and fringe; the bottom is also fringed and fancifully painted as high as the knee. As it is very loose it is enclosed round the waist with a stiff belt decorated with tassels and fastened behind. The arms are covered

1 Original Journals of the Lewis and Clark Expedition, Thwaites ed., 1905, vol. I, p. 222.

8 Voyages, vol. I, pp. xc, xci. 
to the wrist with detached sleeves, which are sewed as far as the bend of the arm ; from whence they are drawn up to the neck, and the corners of them fall down behind as low as the waist. The cap when they wear one, consists of a certain quantity of leather or cloth, sewed at one end, by which means it is kept on the head, and, hanging down the back, is fastened to the beit as well as under the chin. The upper garment is a robe like that worn by the men. Their hair is divided on the crown and tied behind, or sometimes fastened in large knots over the ears."

The dresses illustrated are alike on both sides and are each made of two nearly rectangular pieces of skin of about equal size, dressed without the hair. The piece forming the upper portion of the garment is folded horizontally through the center, then perpendicularly in the middle. A slit is cut through the upper half of the second fold for one arm. The upper folded edges are joined over the shoulders with a short strap and thongs, but the side for the other arm is left open. The second piece forming the skirt is broader at the lower edge to give fulness. It is folded once perpendicularly and the edges at the right side are sewed together. The skirt is then joined to the upper part of the garment by sewing its upper edge to the lower edge of the inner fold of the waist. There is an ornamental band about two inches in width joined at its upper edge to each skirt not far from the bottom. Both garments are ornamented with the characteristic linear designs used upon women's clothing in early times.

The upper portion of the dress shown at $a$ is ornamented with blue beads and brass buttons, doubtless obtained from the Hudson Bay Company traders. Below are horizontal and perpendicular bands of lines seared with a hot bone. The skirt is decorated with symbolic lines and bars in blue, green, yellow, red, and white porcupine quills, with tufts of red worsted at intervals. The applied band near the bottom is covered with a blue bead ground-work with transverse ladder-like bars of white beads. This is bordered on the lower edge with pendants of tin and deer hair. The primary function of this ornamental band is probably to strengthen the lower portion of the skirt.

The accompanying label, written in the same hand as many others from the Peale Museum, is as follows: "Indian Hunting 


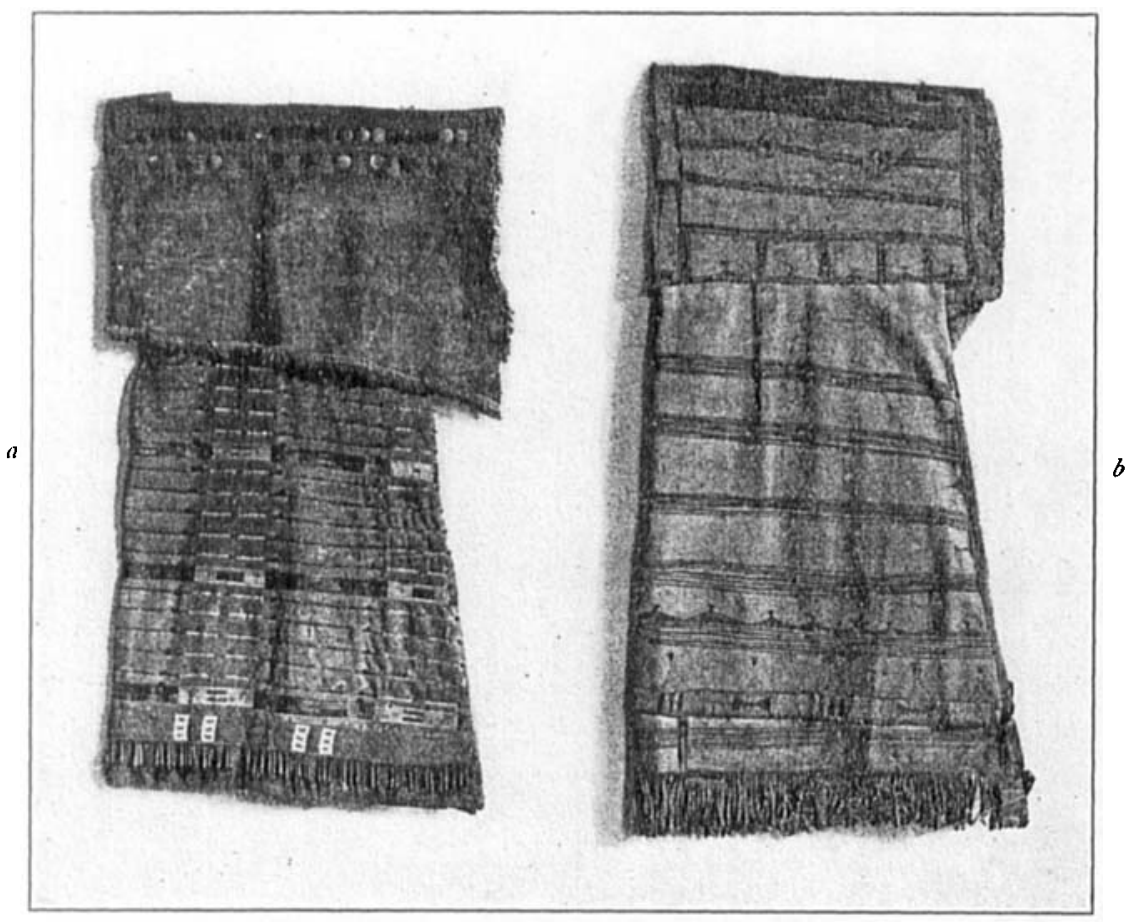

Women's dresses. Cree Indians. Assiniboia, Canada

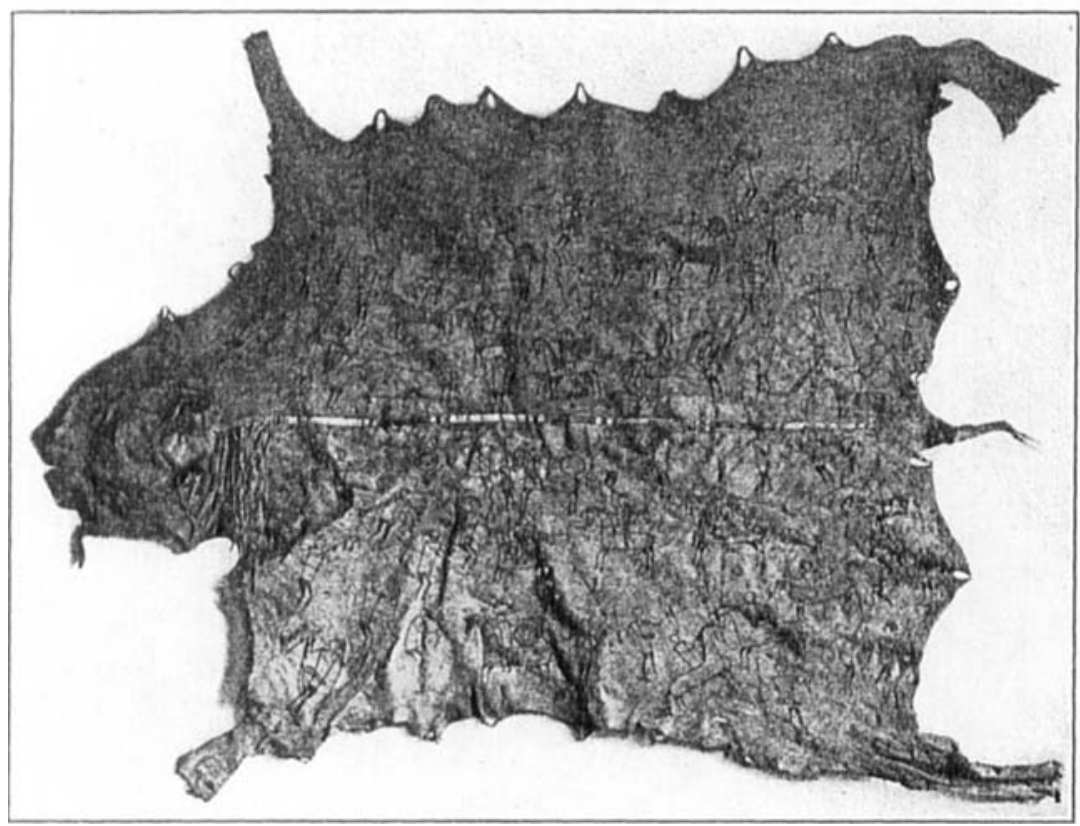

Buffalo robe painted by a Mandan man with design rejresenting a battle fought about $\mathrm{I} 797$ by the Sinux and Arikara against the Mandan, Minitari, and "Ahwahbarways" (Amahami) 


\section{,}


Shirt made of Buffalo skin. This was formerly owned and worn by Capt. Clark in his Exploring Expedition. Presented to Peale's Museum by Capt. Lewis and Clark."

The other dress (b) is ornamented with painted lines and characteristic figures in red and black. A bar along the upper part of the waist, the disks on the breast, the band near the bottom of the skirt, and the ornamental figures just above this band are wrought with blue and green beads. The label, written in the same hand as the other, reads: "Indian Hunting Shirt formerly owned by Capt. Lewis. Presented to Peale's Museum by Capt. Lewis and Clark."

Peabony Museum, Harvard University, Cambridge, Mass. 